\title{
The Phases of Dying in Organizations - A Case Study for New Business
}

\author{
Bruno Inácio da Maia ${ }^{1^{*}} \quad$ Lorena Correa Seiler $^{2} \quad$ André Hideto Futami $^{3} \quad$ Marco Aurélio de Oliveira ${ }^{3}$ \\ 1.Master in Production Engineering, Educational Society University of Santa Catarina - UNISOCIESC, CEP: \\ 89227-753, Santa Catarina, Brazil \\ 2.MBA in Business Management, University of Sao Paulo /ESALQ, CEP: 13418-900, Sao Paulo, Brazil \\ 3.PhD in Production Engineering, Educational Society University of Santa Catarina - UNISOCIESC, CEP: \\ 89227-753, Santa Catarina, Brazil
}

\begin{abstract}
This paper discusses a case study on the performance of organizations and their relationship to the stages of dying proposed by Kübler-Ross. Through this study it is possible to verify that the negative results of the organizations are justified by the stages of the die and that the executives generally protect the decision making to the maximum before the bankruptcy of the organizations for common reasons. The results serve as a reference for organizations and show that the solution is directly linked to new business
\end{abstract}

Keywords: new business, strategy, business environment

\section{Introduction}

The scientific and technological transformation witnessed in the last decades acts as a catalyst in the development of organizations and the need for reinvention and self-analysis is constant. Changes in the business environment, fostered by the rapid change in the custom of the population, forces organizations to reinvent themselves to stay in the market (BARNEY,1991; JOHNSON, CHRISTENSEN \& KAGERMANN, 2008; TEECE, 2010; KIM \& MAUBORGNE, 2005; CAND, 2016).

The companies have difficulties to keep up with the changing dynamics in the business environment they are undergoing, many only realize that the trends are different and that the market changed when the financial result of the operation is determined, and this result presents losses with margins which were deteriorated.

One can summarize the competitive dispute as the result of more than one interested in the same objective, adopting similar standards to obtain this same goal in common. In this way, it is possible to affirm that there are standardizations of methods and ways of competition for the same goal in common. When a competitor adopts different methods and manners there are ruptures of competitiveness, which can be positive, generating improvements in results and gains in market share, as it can be negative burdening the operation and inflating the cost of products, among others (BARNEY,1991; HAMEL \& PRAHALAD, 1995; PORTER, 1999; SCHILKE, 2014; DA MAIA, et. al, 2016).

This view is corroborated by some principles as put by Miniard, Engel, and Blackwell (2000), mainly by the concept of operant conditioning, which causes organizations to repeat in the future the similar behavior for which they have been rewarded in the past. However, probably the future will not behave in the same patterns and concepts of the past, the greater the success obtained in the past the greater the probability of failure in the future if the company does not update itself in the business environment.

The fact that organizations ignore the changes and updates of the business environment architect to the very bankruptcy of the operation. Competition when very fierce can cause losses for organizations and in certain cases, reflecting on the market and customers. As posed by Elizabeth Klübler-Ross in 1981, terminally ill patients try not to accept, refute, and bargain with death, which is similar with organizations. The phases of the "stages" of dying are similar between the sick and the organizations, and can be evaluated according to the next steps of this article.

\section{New Business}

According to KIM (2005) to operate in blue oceans or unexplored waters, it is necessary to rearrange the organization or redirect its strategy to these opportunities, promoting changes in its way of acting in the market and offering products differentiated from the one of the competition, promoting innovations in the market.

For HAMEL and PRAHALAD (1995) the competition for the future is based on the mapping of the organization's essential competences, which may need to define an agenda for the creation of new competencies or the development of already existing competencies, competitors to have the ability to generate knowledge, train, repeat and all are engaged in the main business of the organization. As a main product, the products offered should provide access to new markets, be difficult to imitate and offer real benefits to customers.

The authors of the Balanced Score Card, KAPLAN and NORTON (2001) defend the idea that the evolutionary organization that stands out among competitors in other markets needs to define its pillars around people, processes, clients and finances supported by vision and strategy Organization. The strategic map must be 
defined with the control guidelines and the performance panel should be defined, where the definition of each topic to be monitored should be monitored along with the unit of measure and form of measurement KAPLAN and ATKINSON (2015).

In his book called quantum performance, HRONEC (1994) proposes the quantum measurement model which argues that the organization to be differentiated and superior to competitors in the market must measure its performance indicators, these being its vital signs, making constant updates. As the results are achieved positively the organization stands out in the market until it reaches the point of breaching current standards and creating new opportunities, thus placing it in a privileged place with little or no competition.

CHRISTENSEN (2013) theory states that breakthrough innovations develop new markets and new consumers; these innovations feature products with attributes differentiated from those already in the market or governed by standards.

As processes are established, organizations that develop disruptive products gain momentum in the marketplace, which attracts more customers by presenting new product features.

According to TERRA (2005) and NONAKA and TAKEUCHI (2008), the possibility of creating new opportunities and developing new product and market concepts is focused on knowledge management. The organization needs to develop the system and enable capabilities to translate tacit knowledge (which is with each individual attributed to their experiences, beliefs and culture) into explicit knowledge (formalize in documentation, training, assists, etc.)

It is necessary, according to the authors, to combine knowledge, which is called a systemic process of concepts in a knowledge management system, which allows reconfiguring the existing information bases through classification, information processing, addition, concatenation, combination, and categorization of explicit knowledge, which can lead the organization to gain new knowledge and break down barriers.

According to SCHUMPETER (2000), the organization that obtains an advantage among competitors is one that corrupts the existing economic order, mainly by launching new products to the market, by innovating insertion of forms of organizational structure or by the exploitation of new resources materials. The theory in question is "creative corruption", which is about the fundamental planned action that initiates and continues the cycle of consumerism, developing differentiated products, new markets and offering alternatives to less efficient and more costly conventional methods. Increases in new technologies evidence the obsolescence of conventional manufacturing systems and replace them, so the process is endless. In this way, the organization's creativity allows the generation of better products, with greater margins and with a vast market.

KOTLER (2000) approach proposes that the organization make its strategic business product planning that needs to be conducted as a customer satisfaction process, not just as a product manufacturing process.

The products are transient, but the real needs and the portfolio of customers are long lasting. For the author, the organizational rupture to raise new markets and new products can be found in the three dimensions conjuncture: customer groups, customer needs and technology.

According to PORTER (1990) and PORTER (2001); The competitive advantage of an organization is rooted in the framework of generic strategies, which must be balanced with the five competitive forces. Strategies, defined as total cost leadership, differentiation or focus, would allow companies to apply the five competitive forces and achieve a different performance and superior to their competitors, thus launching the organization to a different market level, creating new opportunities and operating sovereign way.

The positive performance of the organization can be maintained if the strategy is rooted in the prospection of new markets, increasingly distancing the organization's comfort to operate in a traditional way in the known market.

\section{Change Curve}

Death is an undeniable reality, though we know little of it. The studies made by Elisabeth Kübler-Ross, begun in the sixties, in the context of living more than 200 terminal patients, define the psychological reactions to the proximity of her death. In the book entitled "On Death and Dying," the author identified denial, anger, depression, negotiation, and acceptance as the five types of emotional reactions people may experience in the face of a diagnosis of serious illness or incurable.

With the help of Figure 01, the patient's reactions from the moment of consciousness about the fatal disease until the moment of death can be illustrated in a step-by-step way. 


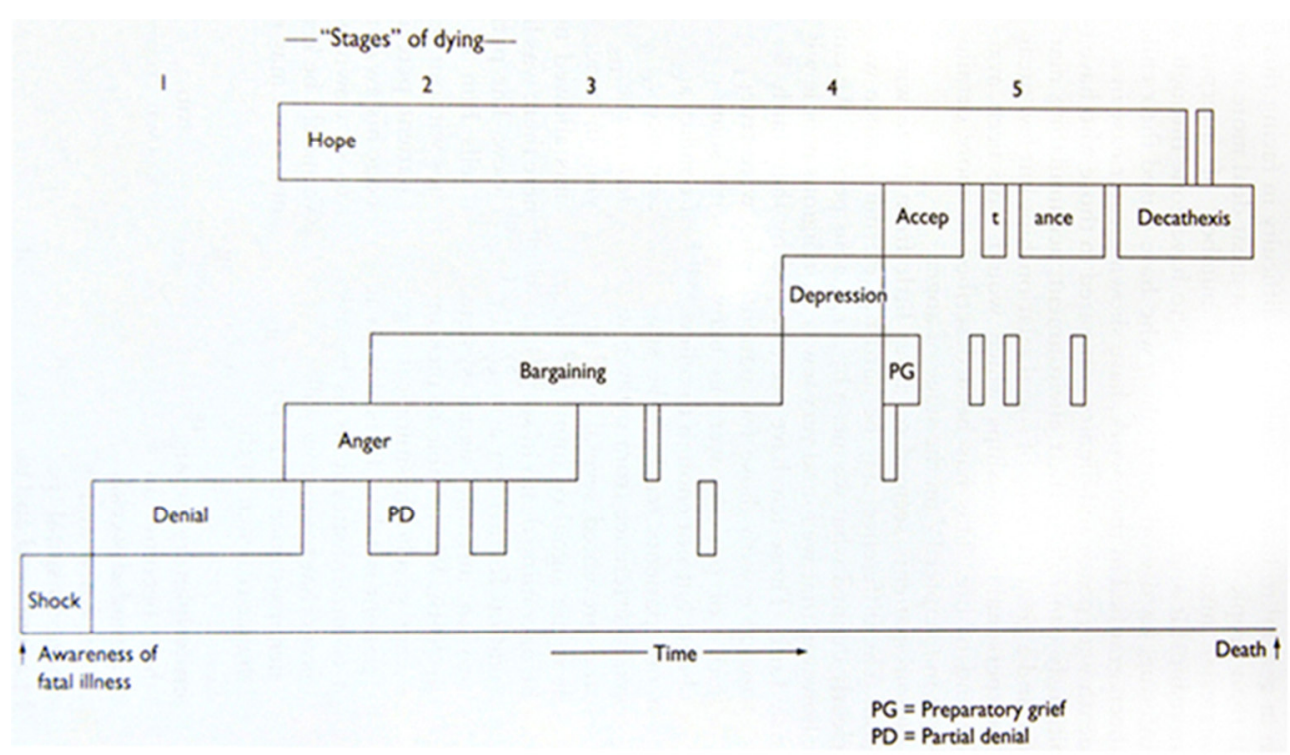

Figure 01: Stages of Dying - KÜBLER-ROSS (1981)

In the 5 types of reactions listed by Kübler-Ross, hope is present in almost all forms of patient reaction, not being present in the denial phase because this is the moment when the patient does not believe in the possibility of being ill or mistrusts the outcome of the disease diagnoses. With the aid of Table 01 it is possible to understand the context about each type reaction in relation to the stage in which the patient is in that particular phase.

Table 01: Context of Reaction of the Sick

\begin{tabular}{|c|c|c|}
\hline Steps & Reactions & Context \\
\hline 1 & Denial & $\begin{array}{l}\text { Psychic defense that makes the individual end up denying the problem, tries to find some } \\
\text { way of not getting in touch with the reality of death. It is common for people not to want } \\
\text { to talk about it either. }\end{array}$ \\
\hline 2 & Anger & $\begin{array}{l}\text { The individual revolts with the world, feels wronged and does not conform because he is } \\
\text { going through it. }\end{array}$ \\
\hline 3 & Bargaining & $\begin{array}{l}\text { The individual begins to negotiate, beginning with himself, ends up wanting to say that he } \\
\text { will be a better person if he comes out of that situation, makes promises to God and uses } \\
\text { his faith. }\end{array}$ \\
\hline 4 & Depression & $\begin{array}{l}\text { The individual retreats into his inner world, isolating himself, feeling melancholy feeling } \\
\text { weak in the face of the situation. }\end{array}$ \\
\hline 5 & Acceptance & $\begin{array}{l}\text { Stage in which the individual does not despair and can see reality as it really is, being } \\
\text { ready to face loss or death. }\end{array}$ \\
\hline
\end{tabular}

Over the years the study developed by Kübler-Ross was adapted to the curves of change used in the development and improvement of personnel. Consulting agencies and companies started to join this methodology to develop internal programs, using as a tool for the development of leaders and as a way to explain the stages of personal transformation (CARTWRIGHT \& COOPER, 1990; CORR, 1993; BRUGHA, 1998; SHEARD \& KAKABADSE,2002; GEORGE 2016).

\section{Methodological Procedures}

This article was developed based on 2 distinct large companies, both compete in the same market and compete with each other. The two organizations manufacture the same types of products, denominated in the market as commodities, have the same quality certifications, manufacturing equipment and organizational structure are similar, in proportion to each organization, i.e., the study bases are the same, validate this research. (GIL, 1999) This study is characterized by being qualitative-quantitative. The prospecting of primary data was collected in loco with interviews with the executives of the companies and access to the database of the two organizations studied, which allowed the minimum access necessary for the collection and subsequent treatment of the data, refinement and analysis of the information, according to recommendations of the competitive intelligence method proposed by FULD (2007).

The interview technique according to Silva, (2006) allows access to information that is not usually written for reasons of personal commitment or different forms of interpretation of the text.

The applied questions were standardized as can be evaluated in table 02 , the context used for the questions is derived from the literature and extracted from the concept of organizational assessment as defined by the 
authors. Six executives of company "A" and 4 executives of company "B" were interviewed.

Table 02: Field Research Questions

\begin{tabular}{|c|c|c|}
\hline Number & Question & Concept of Question \\
\hline 1 & $\begin{array}{l}\text { What is the Organizational Climate perceived by the } \\
\text { executives and the employees, when the financial } \\
\text { goals planned by the organization are not reached? }\end{array}$ & $\begin{array}{c}\text { Waterman, Peters e Phillips (1980), } \\
\text { Burke e Litwin (1992), Galbraith (2002), } \\
\text { Falleta (2008) }\end{array}$ \\
\hline 2 & $\begin{array}{l}\text { How does the Organization perceive that the business } \\
\text { environment is changing? }\end{array}$ & $\begin{array}{l}\text { Weisbord (1978), Waterman, Peters e } \\
\text { Phillips (1980), Galbraith (2002) }\end{array}$ \\
\hline 3 & $\begin{array}{l}\text { What is the organization's reaction to resume margins, } \\
\text { increase revenue, and improve results? }\end{array}$ & $\begin{array}{c}\text { Waterman, Peters e Phillips (1980), } \\
\text { Burke e Litwin (1992), Saeed e Wang } \\
\text { (2014) }\end{array}$ \\
\hline 4 & $\begin{array}{l}\text { How is the organization planning for the medium and } \\
\text { long term? }\end{array}$ & $\begin{array}{l}\text { Weisbord (1978), Waterman, Peters e } \\
\text { Phillips (1980), Galbraith (2002) }\end{array}$ \\
\hline 5 & $\begin{array}{l}\text { What are the bases for planning the sales and } \\
\text { operation plan for the next year? }\end{array}$ & $\begin{array}{l}\text { Weisbord (1978), Waterman, Peters e } \\
\text { Phillips (1980), Galbraith (2002) }\end{array}$ \\
\hline 6 & $\begin{array}{l}\text { Will the organization develop in the short term new } \\
\text { processes (manners / methods and manufacturing } \\
\text { means) for the same products? }\end{array}$ & Christensen (1997), Schumpeter (2000) \\
\hline 7 & $\begin{array}{l}\text { For the next billing planning is the organization } \\
\text { considering innovative products (which the } \\
\text { competition does not yet have)? }\end{array}$ & $\begin{array}{l}\text { Hamel \& Prahalad (1995), Christensen } \\
\text { (1997), Schumpeter (2000). Kim (2005) }\end{array}$ \\
\hline 8 & $\begin{array}{l}\text { The competitive differential that the company has in } \\
\text { relation to its competitors can be summarized as? }\end{array}$ & $\begin{array}{c}\text { Weisbord (1978), Waterman, Peters e } \\
\text { Phillips (1980), Galbraith (2002), Porter } \\
\text { (1999) }\end{array}$ \\
\hline
\end{tabular}

Source: From the Study (2017)

Through the categorization and sequencing of this information, it was possible to understand the dynamics of organizations in relation to their revenues, profitability, how they see their competitors, how they plan the future of operations, and the market they serve.

It is possible to form a conceptual map of the behavior of organizations and to trace the stages of the operation according to the stages originally proposed by Kübler-Ross in 1981.

\section{Results}

With the data collected and later treated it is possible to arrive at evidence that points to the results of certain organizations. As shown in figure 02, the performance of the net income of organization "A" and "B" can be analyzed.

Figure 02: Net Income (\%)

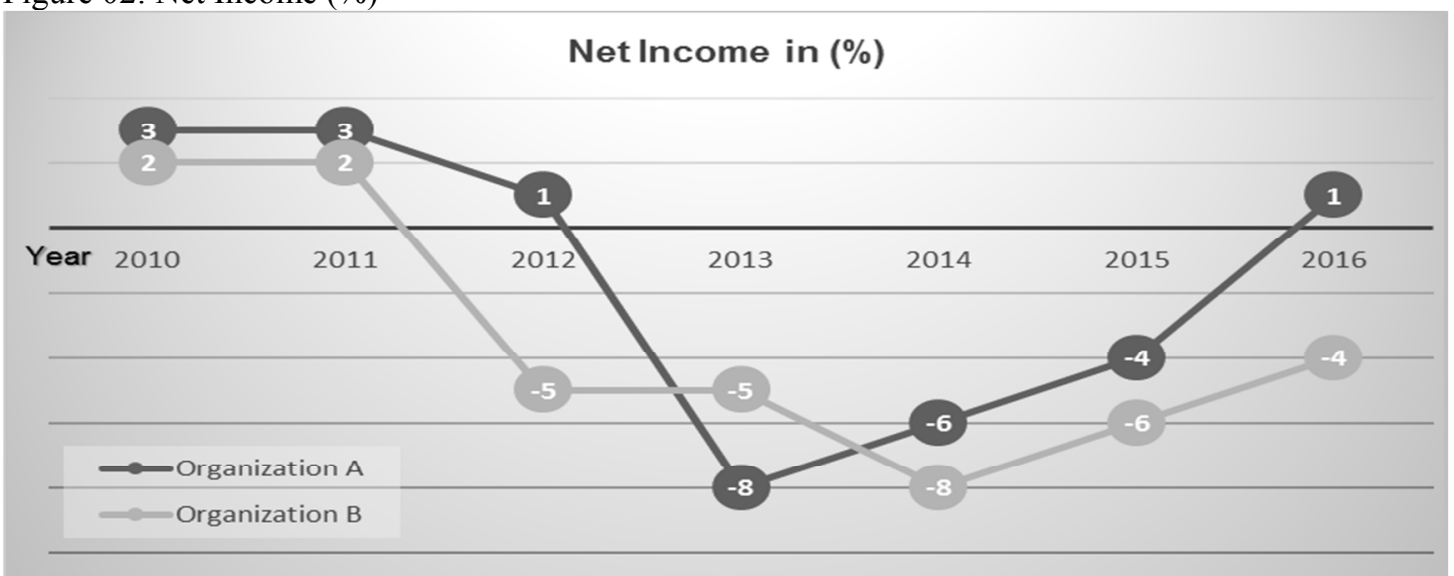

Starting in 2012, the company "B" begins to present negative operating results, in the year 2013 both companies present negative results. The company "B" has been operating for 5 years with negative results, and without presenting positive results, company "A" after 3 years presents a positive result.

The results when compared with the questionnaire responses complement the context that the organizations are inserted and some of the reasons that led the organizations to obtain this result.

The consolidation of the answers between the executives of both organizations presents similar content, characterizing the homogeneity of the perception in relation to the actions that led to this result. In general, the answers were treated as concepts, thus being able to characterize in a simple and direct way the contribution of 
the 10 executives interviewed.

As described in Table 3, an analogy is made with Kübler-Ross's contribution to the dying phases. In the comparison, one can evaluate the stages that lead organizations to have negative results and stay with them until decisions are made about change or that they die.

Table 03: Kübler-Ross Concepts and Organization

\begin{tabular}{|c|c|c|}
\hline & Concept Kübler-Ross (1981) & Organization \\
\hline Denial & $\begin{array}{l}\text { Psychic defense that makes the individual } \\
\text { end up denying the problem, tries to find } \\
\text { some way of not getting in touch with the } \\
\text { reality of death. It is common for people } \\
\text { not to want to talk about it either. }\end{array}$ & $\begin{array}{l}\text { The organization does not accept considering the } \\
\text { changes that occur in the business environment. It } \\
\text { ignores industry trends and refutes the idea of change. } \\
\text { It believes that the unsatisfactory results are timely and } \\
\text { will change. }\end{array}$ \\
\hline Anger & $\begin{array}{l}\text { The individual revolts with the world, } \\
\text { feels wronged and does not conform } \\
\text { because he is going through it. }\end{array}$ & $\begin{array}{l}\text { The organization feels powerless, the results of the } \\
\text { operation do not meet the needs of the company and do } \\
\text { not see changes to improve the result, the } \\
\text { organizational climate is heavy. }\end{array}$ \\
\hline Bargaining & $\begin{array}{l}\text { The individual begins to negotiate, } \\
\text { beginning with himself, ends up wanting } \\
\text { to say that he will be a better person if he } \\
\text { comes out of that situation, makes } \\
\text { promises to God and uses his faith. }\end{array}$ & $\begin{array}{l}\text { The organization uses the plans and opportunities as a } \\
\text { lifeline, it makes promises of change for the future. }\end{array}$ \\
\hline Depression & $\begin{array}{l}\text { The individual retreats into his inner } \\
\text { world, isolating himself, feeling } \\
\text { melancholy feeling weak in the face of } \\
\text { the situation. }\end{array}$ & $\begin{array}{l}\text { The governing body of the organization tries to reverse } \\
\text { the results scenario, draws up plans, and makes } \\
\text { inferences of possible opportunities. }\end{array}$ \\
\hline Acceptance & $\begin{array}{l}\text { Stage in which the individual does not } \\
\text { despair and can see reality as it really is, } \\
\text { being ready to face loss or death }\end{array}$ & $\begin{array}{c}\text { The organization accepts that it is not possible to } \\
\text { operate in the same market in the traditional way. } \\
\text { Actions are taken for new business, innovations and } \\
\text { new markets. Breakthrough Point for New } \\
\text { Organizational Cycle }\end{array}$ \\
\hline
\end{tabular}

In this study, organizations suffered from changes in the competitive environment that are common to both, and which led to the presented results.

The main changes in the business environment were:

+ Imported products: Customers move to direct product import, mainly customers characterized as distributors and industries, this action was taken due to the lower cost of acquisition. Distributors and industries are accounts relevant to these organizations;

+ Market Dispute: As demand declined, it was necessary to sacrifice prices to gain market share, which helped to deteriorate the margins of both organizations.

+ Commodities: Products are in fact standardized, do not present specific requirements or that contain attributes that generate differentiation, in the product is the same anywhere in the world, since they comply with international standards for its design. In this case the differentiation is due to the price strongly influenced by the exchange (which justifies or not the import).

All executives reported that changes in the business environment were drastic, and that despite the issue being addressed at the strategic planning meetings, there was no preparation to override this move or provide resources to offset the losses. In addition to the financial impact on operations, the pressure on the structure and implications on the organizational climate are shared, causing discomfort among employees, conflict of interest between management, reduction of staff, among others.

The company "A" was able to recover the margins due to the complementary strategies of the product portfolio, obtaining the most complete product line in the market so far and obtaining better margins on products that the competition does not have. Inventories, develop world-class suppliers, structure supply and logistics teams, and more.

The company "B" designed the strategy of deactivating product lines that present negative results and develop components conformed to cold to supply the industries in general, taking advantage of the machines and equipment available. It was necessary to adapt operations with secondary processes and obtain quality certifications for supply to certain industries.

Both companies were able to reinvent themselves and improve the results of their operations in the face of environmental changes, but they had to sour the negative result to make these decisions. In the analogy made on the basis of the stages of Klübler-Ross's dying, the stages that organizations spend until they reorient themselves are similar to the steps of the sick, organizations would have died had they not had the decision-making to change. 


\section{Final Considerations}

The behavior of organizations in relation to their preparation for the future and how they will compete in the market is presented in a clear and succinct way. This study shows that the organizations studied did not prepare and that they waited until the environment was modified so that they then acted before their bankruptcy.

The understanding of the executives interviewed among the organizations for the challenges faced by the changes in the business environment are similar, and confirm that the routine issues are usually the priorities of everyday life, deferring guidelines such as future planning and market movements that may impact the operation. Finally, executives point out that planning issues are usually evaluated when the organizational structure is under pressure because it does not generate positive results and emphasize that often the plans are actions that have been used in the past and that have generated good results, however, the future presents forms Different from acting in relation to the past.

An analogy with a proposal developed by Kübler-Ross (1981), may be valid not only for the stages of dying and as a tool for the development of people, but can also be used for organizational management. It is plausible that, like organizations, it is a financial statement for quality verification, such as the possibility of a decision making with lucidity and anticipate how market changes.

Finally, this study brings to the surface an interaction between the areas of psychology and strategic administration, bridging the areas of knowledge and providing contribution to the areas of study.

\section{References}

Barney, J. (1991). Firm resources and sustained competitive advantage. Journal of management, 17(1), 99-120.

Bridges, W. (1986). Managing organizational transitions. Organizational dynamics, 15(1), 24-33.

Brugha, C. M. (1998). The structure of development decision-making. European Journal of Operational Research, 104(1), 77-92

Burke, W. W., \& Litwin, G. H. (1992). A causal model of organizational performance and change. Journal of management, $18(3), 523-545$.

Cartwright, S., \& Cooper, C. L. (1990). The impact of mergers and acquisitions on people at work: Existing research and issues. British Journal of Management, 1(2), 65-76.

Cand, M. L. S. P. (2016). Structure, Strategy and Organizational Design in Albanian Context. Structure, 1(1).

Corr, C. A. (1993). Coping with dying: Lessons that we should and should not learn from the work of Elisabeth Kübler-Ross. Death studies, 17(1), 69-83.

Christensen, C. M. (2013). The innovator's dilemma: when new technologies cause great firms to fail. Harvard Business Review Press.

DA MAIA, B. I., FUTAMI, A. H., DE OLIVEIRA, M. A., \& HURTADO, A. L. B. (2016). Estrutura de Vendas nas Organizações de Conformação a Frio do Norte de Santa Catarina. Revista ESPACIOS $\mid$ Vol. 37 (N $\left.{ }^{\circ} 14\right)$ Año 2016.

Falletta, S. V. (2008). Organizational intelligence surveys. Training \& Development, 62(6), 52-58.

Johnson, M. W., Christensen, C. M., \& Kagermann, H. (2008). Reinventing your business model. Harvard business review, 86(12), 57-68.

Kaplan, R. S., Atkinson, A. A., \& Morris, D. J. (1998). Advanced management accounting (Vol. 3). Upper Saddle River, NJ: Prentice Hall.

KAPLAN, Robert S.; NORTON, David P. Transforming the balanced scorecard from performance measurement to strategic management: Part I. Accounting horizons, v. 15, n. 1, p. 87-104, 2001.

Kim, W. C., \& Mauborgne, R. (2005). A estratégia do oceano azul: como criar novos mercados e tornar a concorrência irrelevante. Tradução de Afonso Celso da Cunha Serra.

KOTLER, Philip. Administração de Marketing-10 ${ }^{\mathrm{a}}$ Edição, $7^{\mathrm{a}}$ reimpressão-Tradução Bazán Tecnologia e Lingüística; revisão técnica Arão Sapiro. 2000.

Kübler-Ross, E. (1981). Living with dying.

Kübler-Ross, E. (2009). On death and dying: What the dying have to teach doctors, nurses, clergy and their own families. Taylor \& Francis.

Galbraith, J. R. (2002). Organizing to deliver solutions. Organizational dynamics, 31(2), 194-207.

George, B.U.C.A.T,.A. (2016). Organizational Change Management: Part Of The Management Strategy. Revista Economică, 68(5).

Prahalad, C. K., \& Hamel, G. (2005). Competindo pelo futuro: estratégias inovadoras para obter o controle do seu setor e criar os mercados de amanhã. Gulf Professional Publishing.

HRONEC, Steven M. Sinais vitais. 1994.

Porter, M. E. (1999). Competição: estratégias competitivas essenciais. Gulf Professional Publishing.

Porter, M. E. (1990). The competitive advantage of nations. Harvard business review, 68(2), 73-93.

Porter, M. E., \& Stern, S. (2001). Innovation: location matters. MIT Sloan management review, 42(4), 28.

INIARD, P. W., ENGEL, J., \& BLACKWELL, R. (2000). Comportamento do consumidor. Rio de Janeiro: 
LTC-Livros Técnicos e Científicos Editora, 439.

Saeed, B. B., \& Wang, W. (2014). Sustainability embedded organizational diagnostic model. Modern Economy, $5(04), 424$.

Silva, G. R. F., Macêdo, K. N. D. F., Rebouças, C. B. D. A., \& Souza, Â. M. A. (2006). Entrevista como técnica de pesquisa qualitativa. Online braz. j. nurs.(Online).

Shepherd, D. A., Wiklund, J., \& Haynie, J. M. (2009). Moving forward: Balancing the financial and emotional costs of business failure. Journal of business venturing, 24(2), 134-148.

Schilke, O. (2014). On the contingent value of dynamic capabilities for competitive advantage: The nonlinear moderating effect of environmental dynamism. Strategic Management Journal, 35(2), 179-203.

Sheard, A. G., \& Kakabadse, A. P. (2002). From loose groups to effective teams: The nine key factors of the team landscape. Journal of Management Development, 21(2), 133-151.

Schumpeter, J. A. (2000). Entrepreneurship as innovation.

Schumpeter, J. (1975). A. 1942. Capitalism. Socialism and Democracy. New York. Harper and Row.

NONAKA, I., \& TAKEUCHI, H. (2008). Teoria da criação do conhecimento organizacional. Gestão do conhecimento. Porto Alegre: Bookman, 54-90.

Terra, J. C. C. (2005). Gestão do conhecimento: o grande desafio empresarial.

Teece, D. J. (2010). Business models, business strategy and innovation. Long range planning, 43(2), $172-194$.

Waterman, R. H., Peters, T. J., \& Phillips, J. R. (1980). Structure is not organization. Business horizons, 23(3), 14-26.

Weisbord, M. R. (1978). Organizational diagnosis: A workbook of theory and practice. Basic Books.

Bruno Inácio da Maia - He holds a Technician in Mechanical Engineering from Tupy Technical School, Graduate in Mechanical Engineering from Pitágoras College (2013), and Master of Production Engineering at University Center of the Educational Society of Santa Catarina UNISOCIESC (2017). They have experience and focus in Mechanical Engineering and Production, with emphasis on Business Management, Product Development and New Business, Launching of Product Lines, Proposals and Project Follow-up, Commercial Strategies such as: Strategic Marketing, Strategic Product Planning and Sales, Innovation, Competitive Intelligence and Strategic Business Planning. At this moment, work as New Business and Marketing Manager at Metallurgical Fey.

Lorena Correa Seiler - She holds a degree in Food Engineering from the Catholic University of Santa Catarina - Jaraguá do Sul (2013). He has experience in the area of Information Technology and Metal Mechanics in the area of product development and customer support. She is currently an MBA in Business Management at the University of Sao Paulo and works as a local innovation agent at the National Research Center.

André Hideto Futami - He holds a degree in Production Engineering (Mechanics) from the Polytechnic School of the University of São Paulo - POLI / USP (1991), master's degree in Production Engineering and Systems from the Federal University of Santa Catarina - PPGEP / UFSC (2001). He holds a specialization in Administration from the Federal University of Paraná - CEPPAD / UFPR (2003). He has professional experience in the area of New Product Development and Product Projects, having worked for eighteen years as a product development specialist in the area of multinational technology in the electro-electronic business. He has a PhD in Product Engineering and Processes at PPGEP / UFSC and is currently part of the faculty of the Master's Degree in Production Engineering at the University Center of the Educational Society of Santa Catarina - UNISOCIESC. Marco Aurélio de Oliveira - He is an electrical engineer at Federal University of Santa Catarina (B.Eng., UFSC 1984), master in Electrical Engineering in the area of Power Electronics and Electrical Drive at Federal University of Santa Catarina (M.Eng., UFSC 1987) and PhD in Production Engineering in Product and Process Engineering at Federal University of Santa Catarina (Dr.Eng., UFSC 2011). Has experience in the area of Electrical Engineering, with emphasis on industrial electronics, systems and electronic controls, working mainly on the following topics; Frequency converter, harmonic content optimization, active filters and pulse width modulation (PWM) modulation. In the area of Mechanical Engineering has been dedicated to work in the field of instrumentation, automation of measurement (equipment and systems), optimization of means and methods of performance testing, reliability in compressors and refrigeration systems, experiment planning. In the area of Production Engineering, he is involved in process reorganization, logistics, product safety and resource management, dealing with aspects related to the administration of teams, methods and procedures, and information systems. He is a reviewer of the journals Expert Systems with Applications (Elsevier), International Journal of Productivity and Performance Management (Emerald) and International Journal of Production Research (Taylor \& Francis), among others. His major areas of interest are systems modeling, process reorganization, lean organization (Lean Enterprise), project leadership, and knowledge management and is currently part of the faculty of the Master's Degree in Production Engineering at the University Center of the Educational Society of Santa Catarina - UNISOCIESC. 